RESEARCH IN SCIENCE EDUCATION -

PAST, PRESENT, AND FUTURE 


\title{
Research in Science Education - Past, Present, and Future
}

\author{
Edited by \\ Helga Behrendt \\ Helmut Dahncke \\ Faculty of Education, \\ University of Kiel, Germany \\ Reinders Duit \\ Wolfgang Gräber \\ Michael Komorek \\ Angela Kross \\ IPN - Institute for Science Education, \\ University of Kiel, Germany \\ and \\ Priit Reiska \\ University of Educational Sciences, \\ Tallinn, Estonia
}


eBook ISBN: $\quad$ 0-306-47639-8

Print ISBN: $\quad$ 0-7923-6755-3

C2002 Kluwer Academic Publishers

New York, Boston, Dordrecht, London, Moscow

Print @2001 Kluwer Academic Publishers

Dordrecht

All rights reserved

No part of this eBook may be reproduced or transmitted in any form or by any means, electronic, mechanical, recording, or otherwise, without written consent from the Publisher

Created in the United States of America

Visit Kluwer Online at:

http://kluweronline.com

and Kluwer's eBookstore at:

http://ebooks.kluweronline.com 


\section{Contents}

Preface

\section{Part 1: Views and Visions of Science Education Research}

D. Psillos

Science Education Researchers and Research in Transition: Issues and Policies 11

E. W. Jenkins

Research in Science Education in Europe: Retrospect and Prospect

P. J. Fensham

Science Content as Problematic - Issues for Research

H. Dahncke, R. Duit, J. Gilbert, L. Östman, D. Psillos, D. B. Pushkin

Science Education Versus Science in the Academy: Questions - Discussion -

Perspectives

\section{Part 2: Scientific Literacy - Conceptions and Assessment}

W. Harlen

The Assessment of Scientific Literacy in the OECD/PISA Project

W. Gräber, P. Nentwig, H.-J. Becker, E. Sumfleth, A. Pitton, K. Wollweber, D. Jorde

Scientific Literacy: From Theory to Practice

T. J. Russell, L. McGuigan

Making Formative Use of a National Summative Assessment Regime

H. Dahncke, H. Behrendt, P. Reiska

A Comparison of STS-Teaching and Traditional Physics Lessons - On the

Correlation of Physics Knowledge and Taking Action

\section{Part 3: Students' Conceptions}

G. Ireson

On the Quantum Thinking of Physics Undergraduates

G. Pospiech

Experiences with a Modern Course in Quantum Physics

M. Komorek, R. Duit, N. Bücker, B. Naujack

Learning Process Studies in the Field of Fractals

M. J. Reiss, S. D. Tunnicliffe

Students' Understandings of their Internal Structure as Revealed by Drawings 
G. Helldén

Personal Context and Continuity of Human Thought; Recurrent Themes in a 107 Longitudinal Study of Pupils' Understanding of Scientific Phenomena

V. Spiliotopoulou, P. Alevizos

Entities of the World and Causality in Children's Thinking

M. Ratcliffe, P. Fullick

Using Media Reports of Science Research in Pupils' Evaluation of Evidence

B. Campbell

Pupils' Perceptions of Science Education at Primary and Secondary School

\section{Part 4: Teachers' Conceptions}

\section{Lang}

Teacher Professionalism and Change: Developing a Professional SelfThrough 131 Reflective Assessment

B. Keogh, S. Naylor, M. de Boo, R. Feasey

Formative Assessment Using Concept Cartoons: Initial Teacher Training in the $U K$

D. F. Treagust, W. Gräber

Teaching Chemical Equilibrium in Australian and German Senior High Schools 143

S. García-Barros, C. Martínez-Losada, P. Vega, M. Mondelo

The Ideas of Spanish Primary Teachers about how to Develop an Understanding 149 of Processes in Science and their Support in Textbooks

J. A. Craven III, B. Hand, V. Prain

Pre-service Elementary Teachers Constructing the Nature and Language of

Science

L. Kyyrönen, M. Ahtee

Combining Knowledge of Physics and Chemistry in Teaching: The Behaviour of a Narrow Jet of Water in the Presence of Charged Insulators

P. Tsamir, D. Tirosh, R. Stavy, I. Ronen

Intuitive Rules: A Theory and Its Implications to Mathematics and Science

Teacher Education

\section{Part 5: Conceptual Change - Teaching and Learning Processes}

S. Vosniadou

Conceptual Change Research and the Teaching of Science

I. Martins, E. Mortimer, J. Osborne, C. Tsatsarelis, M. P. Jiménez Aleixandre Rhetoric and Science Education

S. von Aufschnaiter

Development of Complexity through Dealing with Physical Qualities: One Type of Conceptual Change? 
J. Wilbers, R. Duit

On the Micro-Structure of Analogical Reasoning: The Case of Understanding

Chaotic Systems

P.-L. Lehtelä

Role-playing, Conceptual Change, and the Learning Process: A Case Study of

7th Grade Pupils

H. Fischler, J. Peuckert, H. Dahncke, H. Behrendt, P. Reiska, D. B. Pushkin, M. Bandiera, M. Vicentini, H. E. Fischer, L. Hucke, K. Gerull, J. Frost

Concept Mapping as a Tool for Research in Science Education

P. Buck, P. Johnson, H. Fischler, J. Peuckert, S. Seifert

The Need for and the Role of Metacognition in Teaching and Learning the

Particle Model

M. S. Steinberg, J. J. Clement

Evolving Mental Models of Electric Circuits

P. Colin

Two Models for a physical Situation: the Case of Optics. Students' Difficulties,

Teachers' Viewpoints and Guidelines for a «didactic Structure»

I. Galili, A. Hazan

The Influence of a Historically Oriented Course on the Content Knowledge of Students in Optics

C. Hilge

Using Everyday and Scientific Conceptions for Developing Guidelines of

Teaching Microbiology

H. Saari, J. Viiri

Teaching and Learning the Concept of the Model in Secondary Schools

J.-L. Chartrain, M. Caillot

Conceptual Change and Student Diversity: The Case of Volcanism at Primary

School

O. de Jong, J. van Driel

The Development of Prospective Teachers' Concerns about Teaching

Chemistry Topics at a Macro-Micro-Symbolic Interface

C. Bolte

How to Enhance Students' Motivation and Ability to Communicate in Science Class-Discourse

H. Stadler, G. Benke, R. Duit

How do Boys and Girls use Language in Physics Classes?

\section{Part 6: Instructional Media and Lab Work}

E. Sumfleth, L. Telgenbüscher

Improving the Use of Instructional Illustrations in Learning Chemistry 
S. Pavlinic, P. Buckley, J. Davies, T. Wright

Computing in Stereochemistry - 2D or 3D Representations?

D. Heuer, K. Blaschke

Learning Physics with Multimedia- and Experimental-Supported Workshop Instruction

\section{J. Robertson}

Generating Hypotheses in Scientific Enquiry

A. Berry, R. Gunstone, J. Loughran, P. Mulhall

Using Laboratory Work for Purposeful Learning about the Practice of Science

P.-O. Wickman, L. Östman

University Students During Practical Work: Can We Make the Learning

Process Intelligible?

L. M. M. van Rens, P. J. J. M. Dekkers

Learning About Investigations - The Teacher's Role

S. Allie, A. Buffler, F. Lubben, B. Campbell

Point and Set Paradigms in Students' Handling of Experimental Measurements

E. Whitelegg, C. Edwards

Beyond the Laboratory - Learning Physics Using Real Life Contexts

Name Index

Subject Index 


\section{Preface}

This volume includes articles based on papers presented at the Second International Conference of the European Science Education Research Association (E.S.E.R.A.) held in Kiel, August 31 to September 4, 1999. About 300 colleagues, virtually from around the world - with a particular European focus - participated. Some 200 papers were presented. Three pages synopses of these papers were published in Proceedings of the conference (edited by Michael Komorek, Helga Behrendt, Helmut Dahncke, Reinders Duit, Wolfgang Gräber and Angela Kross). They are available from the IPN homepage: http://www.ipn.uni-kiel.de.

The participants were asked to submit contributions to the present volume. It contains the invited plenary lectures and a selection of the submitted contributions based on reviews by an international board and the editors. The volume mirrors main lines of research in science education in Europe and around the world. The invited lectures provide overviews of the growth of science education research from the past to the present, including views of future developments. Major emphasis of empirical research still seems to be students' conceptions and conceptual change. About half of the contributions fall into that category. In addition, most of the remaining contributions deal with various cognitive issues of teaching and learning science. It was surprising for us that the number of studies on affective issues and gender differences was much smaller than expected.

The Second International Conference of the European Science Education Research Association was gratefully supported by the German Science Foundation (Deutsche Forschungsgemeinschaft). These funds allowed us to invite eminent plenary lecturers. We would also like to acknowledge support by Kluwer Academic Publishers and the International Journal of Science Education. Finally, the Institute for Science Education at the University of Kiel and the Faculty of Education of the University of Kiel supported the conference in various ways.

We are also most grateful to a number of colleagues who helped to organize the conference and the production of the present volume. The following list includes colleagues who served as members of the board of reviewers for the papers submitted to the conference and/or as members of the board of reviewers for the contributions of the present volume:

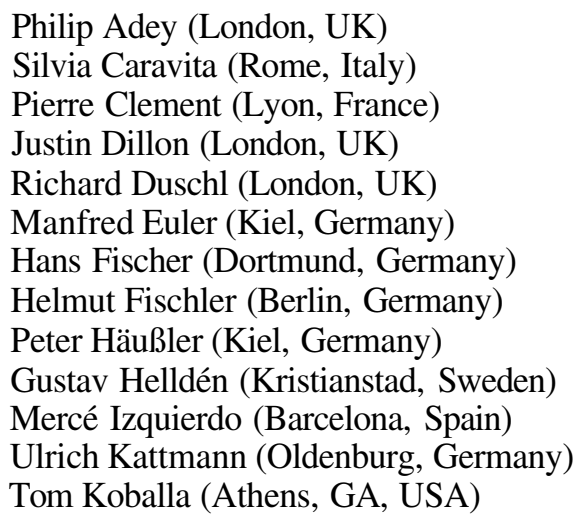


Peter Labudde (Bern, Switzerland)

Piet Lijnse (Utrecht, The Netherlands)

Brunhilde Marquardt-Mau (Kiel, Germany)

Martine Meheut (Paris, France)

Robin Millar (York, UK)

Hans Niedderer (Bremen, Germany)

Jonathan Osborne (London, UK)

Leif Östman (Uppsala, Sweden)

Dimitris Psillos (Thessaloniki, Greece)

David Pushkin (Hackensack, NY, USA)

Christoph von Rhöneck (Ludwigsburg, Germany)

Helga Stadler (Wien, Austria)

Wieslav Stavinski (Krakow, Poland)

Ruth Stavy (Tel Aviv, Israel)

Elke Sumfleth (Essen, Germany)

David Treagust (Perth, Australia)

Rod Watson (London, UK)

Finally, we would like to gratefully acknowledge the tremendous effort made by Ulrike Hennig in transforming the contributions into a form that may be printed. We also like to mention that Valerie Reed carefully checked - and if necessary improved - the English of the contributions and that John-Philip Josten organized the communication with the contributors and reviewers.

The Editors 